\title{
Resources on East Asian Law in the United States
}

Nongji Zhang*

\section{History}

The development of foreign law collections in the United States has been divided into three stages. The first stage started in the nineteenth century with the Library of Congress and the Harvard Law School Library taking the lead in a period of "haphazard growth." "In 1845 it was said, and Professor Greenleaf1 reported, that the Harvard Law Library surpassed every other law library in the United States, and also that no other law library in England or on the Continent was its equal in scope."2 At the Library of Congress, "the need for foreign legal research sources, especially in times of hostilities with other nations, intensified the Law Library's acquisition efforts over the years to such an extent that certain collections in the Law Library exceed those of the countries of origin." 3 The early collections of foreign laws include historical laws and treatises from France, Spain, Russia, Great Britain, and other Commonwealth countries. The laws of Great Britain are the most extensive because of their significance in the

* Bibliographer for East Asian Law at Harvard Law School Library. I am very grateful to the following individuals for providing information and research materials for this article: Wendy Zeldin, Senior Legal Research Analyst with Directorate of Legal Research, The Library of Congress; Rob Britt, Japanese Legal Materials Specialist with the Marian Gould Gallagher Law Library, University of Washington; Yukino Nakashima, Curator for the Japanese Collection with the Arthur W. Diamond Law Library, Columbia Law School; Evelyn Ma, Reference Librarian with the Lillian Goldman Law Library, Yale Law School; and John Hostage, Authorities Librarian with Harvard Law School Library. I also want to thank Grace Wiersma, Cataloging \& Metadata Services with MIT Libraries, Deborah Weiss, Romance Language Cataloger and Bridget Reischer, Bibliographer for Western European and International Law with Harvard Law School Library, for their editing work for this article. I am very indebted to William McCloy's insightful remarks and suggestions for this article.

1 Simon Greenleaf (1783-1853) was Harvard Law School professor from 1833 to 1840s. He contributed extensively to the development of Harvard Law School, including expansion of the Harvard Law School Library s

2 Kurt Schwerin, Law Libraries and Foreign Law Collections in the U.S.A, 11 INTL \& ComP. L.Q. 560 (1960). Kurt Schwerin was Librarian of Northwestern University Law Library from 1964 to 1970.

3 LaW Library of CONGREss (US.), Library of CONGREss LaW Library: An Illustrated Guide 12 (Library of Congress 2005). 
United States and their influence on U.S. law. 4

The second stage began around the turn of the 20th century. During this period, the "systematic growth" of foreign law collections began to meet an increasing demand for knowledge of legal institutions of foreign countries. Particularly during the years 1900 to 1925, whenever great libraries became available for purchase, the Harvard Law School acquired them. In 1916, when Roscoe Pound became Dean (1916-1936) of Harvard Law School, "out of a total of 171,629 volumes in the Library, 47,442 were in the fields of Roman and foreign law (the British Empire not included)."5

The third stage started after the two world wars. Due to the emergence of the United States as the leading world power, the growth of international organizations and the expansion of international trade, a "renewed emphasis on the foreign law collections" took place. 6 By 1962, the Library of Congress, Harvard, Michigan, Columbia, Yale, the Los Angeles County Law Library, Northwestern, the Association of the Bar of New York, Tulane and Chicago became the top 10 owners of foreign law collections in the United States.

So far, existing studies on foreign law collections have discussed only European and Latin American materials. Few studies have explored the development of East Asian law collections. The question still remains as to when libraries in the United States began to collect East Asian law materials. An examination of the developmental paths of major East Asian law collections may help us to gain perspective on this issue.

The literature reveals no indication when the Library of Congress acquired its first Chinese, Japanese and Korean (CJK) law books, "apparently some Japanese laws had been obtained as of circa 1930."7 One related event was that in the late 1940s, the Law Library of Congress received funding through the Chinese Emergency Aid Program of the Department of State for seven Asian lawyers who then published works on the law of various Far Eastern countries between 1950 and 1955.8

It is commonly believed that the Harvard Law School's collection of East Asian law materials began at the turn of 20th century. A random survey of the Harvard Law School Library Accessions List found that gift materials from East Asia arrived as early as 1900. The earliest date found in the literature concerning acquisitions of East Asian legal materials was in the 1920s. As Roscoe Pound later wrote: “In 1927, Dr. J. E. de Becker, the translator of the Japanese Codes and authority on Japanese law, gave the

4 For more information concerning the Law Library of Congress's foreign rare book collection, see US LAW LIBRARY OF CONGRESS, RARE BOOK COLLECTION, available at http://memory.loc.gov/ammem/ awhhtml/awlaw3/rare_book.html (last visited on Oct. 6, 2008).

Schwerin, supra note 2, at 561.

Id. at 563.

E-mail from Wendy Zeldin to author (Apr. 29, 2008) (on file with author).

8 US Law Library of Congress, supra note 3, at 22-23. 
Library a large collection of important Japanese law books which, added to what had previously been acquired, and with later additions, has resulted in a substantially complete collection." 9

Eldon R. James, Librarian of Harvard Law School from 1923 to 1942, made a major effort to raise a substantial amount of money for the Law School's acquisitions of books. In 1930, Mr. James hired Shigemaru Shimoyama (下山重丸), a graduate of the Harvard Graduate School of Design, to work for the Library. In 1935 the Library sent staff (if not Mr. Shimoyama) to Japan and bought a sizable collection of Japanese manuscripts and printed books. Large shipments of book acquisitions arrived in 1936. The Library received 58 Japanese titles on March 7, 65 titles on March 21, 100 titles on Apr.4 and 150 titles on July 30 . These materials dated from as early as the twelfth century up to the modern period.10 By 1945, the Harvard Law School Library's collection of Japanese materials reached 1,400 volumes. Also in 1936, Harvard Law School Library began to receive Chinese books purchased from Soochow University Law School and Peking Union Bookstore.

Dean Pound had the vision and interest to collect foreign law materials. He was also involved in the development of legal education and the legal system in China. He traveled to China a number of times during the 1930s and 1940s to teach in Chinese law schools. He served as advisor to the Chinese Ministry of Justice from 1946 to 1948. In 1965, Professor Jerome Cohen, a China law expert, founded one of the nation's oldest and most extensive Asian law programs, the East Asian Legal Studies Program at Harvard Law School. The China connections of Dean Pound and Professor Cohen have likely contributed to the early development of the Chinese law collection at Harvard Law School.

The Columbia Law School began to collect Chinese, Japanese and Korean language legal materials in the early 1980s. "In 1982, the Arthur W. Diamond Law Library at Columbia Law School received a private law collection donated by the family of the late Justice Jiro Tanaka, who served as a Supreme Court Justice of Japan between 1964 and 1973. Building on this collection, which was considered the finest private law collection in Japan, the Diamond Law Library began the development of a comprehensive Japanese law collection in 1984."11 Since 1983, Columbia Law School has also collected Chinese and Korean materials on law.

9 Roscoe Pound, The Harvard Law Library, 5 HARv. LiBR. Bull. 298 (1951).

10 James Kanda, The Japanese Archives of Harvard Law School Library 1 (Dec. 1975) (unpublished manuscript, on file with Harvard Law School Library).

11 Toshiba Library for Japanese Legal Research, available at http://www.law.columbia.edu/library/collections/toshiba (last visited on Feb. 8, 2008). 
"In more recent years, the Toshiba Library12 received large private collections from a former Supreme Court Justice, Itsuo Sonobe, and from Professor Koichi Kikuta of Meiji University, as well as duplicate materials of the Law Faculty at Meiji University. With the support of Nagashima, Ohno \& Tsunematsu, the Library acquired approximately 800 volumes of important case reporters, journals and statistical materials."13

At the Gallagher Law Library of University of Washington, “The Library's Asian law collections had their beginnings in the 1930's with gifts of Chinese and Japanese legal materials, including a substantial donation of books by the Japanese Ministry of Justice."14 Dr. Arthur Beardsley, the head law librarian of the Law Library from 1922 to 1944 was later credited with starting the library's systematic collecting of Chinese, Japanese, and Korean materials following the gift of a modern Japanese law collection from the Japanese-American Society, just before World War II.15 In the early 1960s, the Law School received a grant from the Ford Foundation. This grant allowed the Library's Japanese law collection to expand and provided for the hiring of a full-time Japanese law scholar, Professor Dan Fenno Henderson who started the Asian Law Program at the Law School in 1962. To support the Asian Law Program (which was primarily a Japanese Law Program in those days), Japanese speaker, T. Susanne Lee (Takika Yamada Lee or "Susie" Lee) was hired to develop the Japanese as well as other Asian and foreign law collections. 16 With the hiring of the Assistant Librarian for East Asian Law in 1989, the Library's Chinese and Korean legal materials increased greatly, while support of the Japanese collection continued. 17

\section{Curent State and Speical Features}

Today, many major US law school libraries have set up special budgets or received contributions from their Asian law programs for the development of East Asian law collections. They continue to benefit from the support of foundations such as the Ford Foundation, the Japan-U.S. Friendship Commission, the Japan Foundation, the Korea

12 The Toshiba Library for Japanese Legal Research refers to the collection of Japanese law in the Arthur W. Diamond Law Library at Columbia Law School.

13 See supra note 11.

14 Marian Gould Gallagher Law Library, East Asian Law Department History, available at http://lib.law.washington.edu/eald/eald.html, (last visited on Oct. 5, 2008).

15 Pegeen Mulhern: Marian Gould Gallagher's Imprint on Law Librarianship-The Advantage of Casting Bread upon the Waters, available at http://aallnet.org/products/pub_llj_v98n02/2006-20.pdf (last visited on Oct. 5, 2008.

16 William B. McCloy, correspondence to Eric Lee (Sept. 29, 2008) (on file with author).

17 E-mail from Rob Britt to author (Apr.15, 2008) (on file with author). 
Foundation. In addition, Taiwanese, Japanese and Korean governments, courts, law schools, as well as alumni groups have donated substantial gifts of books, which are vital in building up strong and unique collections.

The Library of Congress Law Library, Harvard Law School, Columbia Law School, and the University of Washington hold the largest East Asian law collections in the United States. Other law schools, including those at the University of Michigan, Yale University, the University of California at Berkeley, and Washington University in St. Louis, also have substantial materials on East Asian law.

There is no doubt that the Library of Congress owns the largest of all East Asian law collections in the United States. The record shows that there are 16,002 classified titles for China (including 3,646 titles for Taiwan), 9,229 for Japan, and 2,833 for Korea. There are also about 500 titles in Chinese, which are either unclassed or uncataloged. There are a sizable number of unclassed Japanese legal titles, estimated at over 25,000 titles, although some may be duplicates of classed titles. A rough account shows 4,000 titles of Korean law books which are unclassed. In terms of volumes, the whole Chinese, Japanese and Korean collection exceeded 80,000 volumes by 1978.18 Special features of this collection include extensive sets of official gazettes from China and Japan, a rich core of historic Japanese legal materials, and a very extensive collection of Japanese legal periodicals. Some four hundred titles of traditional Chinese legal material, many of which are multi-volume compilations, date from the eighteenth and nineteenth centuries; rare Korean legal materials, including the six-volume title Kyongguk Taejon, and another 23 volumes from the Chosun Dynasty (1392-1910) are also included. "Although legal material from the Democratic People's Republic of Korea (North Korea) is scarce and very difficult to obtain, the Law Library's collection is one of the most complete outside Korea or Japan."19

Harvard Law School Library's collection on East Asian Law exceeds 38,800 titles (volume count not available). This number includes 19,000 titles on the People's Republic of China (P.R. China or PRC) law; 2,500 titles on the Republic of China (Taiwan or R.O. China) law; 14,800 titles on Japanese law; and 2,500 titles on Korean law. The Library has more than 17,800 titles in Chinese language, 13,717 in Japanese, and 2,274 in Korean. 20 This collection features the nation's most comprehensive resource (including legal newspapers and electronic resources) on modern Chinese law, and a collection of Japanese manuscripts and early printed books that is considered to be one of the best outside Japan.

The Arthur W. Diamond Law Library at Columbia Law School has more than 27,811

18 See Zeldin, supra note 7.

19 US Law Library of Congress, supra note 3, at 150.

20 HOLLIS report provided by John Hostage (Apr. 15, 2008) (on file with author). 
titles dealing with Chinese, Japanese and Korean law. Among this number, 18,338 titles (more than 23,000 volumes) are Japanese legal materials. The Library has 3286 titles on Chinese law and in Chinese; and 896 titles on Korean law and in Korean.21 The Library also has more than 5291 titles of Western language materials concerning East Asian law. This collection currently is one of the largest and most comprehensive Japanese law resources outside Japan.

The Marian Gould Gallagher Law Library at the University of Washington has more than 23,824 titles in Chinese, Japanese or Korean language, or on East Asian law. Among this number, 5379 titles (10,189 volumes) are in Chinese, 12,299 titles (33,164 volumes) are in Japanese, and 1,204 titles (2,731 volumes) are in Korean. In addition, the Library holds over 4,942 titles (7695 volumes) in Western languages concerning East Asian law. ${ }^{22}$ The strength of this collection is contemporary Japanese legal research materials.

\section{The Personnel and their Reponsibilites}

Given the complexity of legal information and language barriers, it is very difficult for a librarian to become a master of legal information from every jurisdiction of East Asia. William McCloy, the former Assistant Librarian for East Asian Law of the Gallagher Law Library of University of Washington, provides a rare example of such mastery. He has extensive knowledge of Chinese, Japanese and Korean legal materials. Among his accomplishments, he was President of the Council on East Asian Libraries (2000-2003). He participated in the enhancement of table T.2 of The Bluebook: A Uniform System of Citation (18th ed. 2005). His contributions to East Asian and law librarianship are widely recognized and appreciated.

There are only a few law libraries in the United States fortunate enough to have fulltime East Asian law specialists on staff. The Law Library of Congress and the law libraries at Harvard, Yale, Columbia and the University of Washington are the only ones who employ specialists in East Asian law bibliography and cataloging. Although these professionals may handle one or more languages, their specialties are generally in a particular jurisdiction of East Asia. To provide comprehensive reference service concerning all of Chinese, Japanese and Korean law, the cooperation and communication among these librarians is absolutely essential. Other law libraries holding East Asian law materials usually rely on their foreign law bibliographers for reference help or on a staff member who knows the language but deals with Anglo- 
American legal materials as his/her primary duty.

As mentioned earlier, US law libraries have been collecting East Asian legal materials since 1900, but not until much later were professional librarians hired to work exclusively with East Asian materials. The Library of Congress established the Far Eastern Law Section in 1954, which achieved divisional status in 1957. Mr. Choung Chan, a lawyer, became the first Chief of this unit serving the legal research needs of the Congress. Currently, the Library has one cataloger for Chinese law, two for Japanese law, and one for Korean law. CJK law serials are cataloged by three to four different catalogers in the Serial Record Division. The Library has Chinese and Japanese law specialists to develop the respective collections, but most of their day-to-day work centers on providing research and reference services to the Congress and the general public. At present the legal specialist for Japan also covers Korea. There is no Korean law expert for research, selection and reference. 23

In 1986, Kristin Fryklund became the first person hired by the Harvard Law School Library to handle East Asian materials. She worked as the East Asian language cataloger. A year later, Scott Edward Harrison succeeded Ms. Frykland to become the first Bibliographer for East Asian Law. This was the new beginning for the Library to systematically collect East Asian legal materials. In 1997, I succeeded Mr. Harrison as Bibliographer for East Asian Law at Harvard Law School Library. My job responsibilities involve every aspect of selection, acquisition, and cataloging of CJK materials, as well as providing reference services, and serving as liaison to the East Asian Legal Studies Program. In 1999, Mariko Honshuku was hired to assist with cataloging, acquisitions, and reference service for Japanese materials. The Library also hires temporary staff to assist with Chinese and Korean cataloging from time to time.

In 1991, the Arthur W. Diamond Law Library at Columbia Law School created a permanent position of Japanese law curator with an endowment from the Toshiba Corporation in Tokyo. Since then, Yukino Nakashima has been the Japanese Law Curator at Columbia Law School. She handles both Japanese and Korean materials, while Chinese materials are selected and cataloged by other staff members.

In the early 1960s, T. Susanne Lee came to the Gallagher Law Library at the University of Washington. She was responsible for the extensive development of the Library's Japanese and other Asian and foreign law collections. "She not only organized the cataloging of the Japanese collection, she also assisted in the continued growth of the Asian law collection." 24 She had a long tenure at the Library and built

23 See Zeldin, supra note 7.

24 See Mulhern, supra note 15. 
that collection for around the first 25 years of its existence. 25 In 1987, Rob Britt was hired to work, part-time at first, then full-time soon after, in the Library's Comparative Law Department. In 1989 Bill McCloy became the first Assistant Librarian for East Asian Law and manager of the East Asian Law Department. The retirement of Mr. McCloy in 2008 created the opportunity for Mr. Britt to assume more responsibility for collecting East Asian materials.

Evelyn Ma is Asian Law Reference Librarian at the Lillian Goldman Law Library of Yale Law School. Her responsibilities include selecting and cataloging of CJK materials, as well as providing reference assistance and serving as liaison to the China Law Center at Yale Law School. The Library's CJK language materials are mainly donated by libraries overseas or via exchange programs. Prior to her arrival, in 2005, Daniel Wade, Associate Librarian for Foreign and International Law, handled selection of CJK materials with the assistance of the East Asian Library. During this period, the Library had used OCLC's off-site Chinese acquisitions-cataloging service.

\section{Obstacles and Trends in East Asian Legal Collections in the United States}

Recent developments in information technology, the publishing industry, and East Asian legal studies have contributed to the changes in East Asian law collections in the United States. With the increasing demand for electronic access to research materials in U.S. law schools and limited budgets for East Asian law materials, law libraries have been slowly and cautiously adding online East Asian resources to their collections. Demand for materials with interdisciplinary approaches to legal research is increasing. More students are writing papers in the areas of business law, the application of law, and the practice of law. Empirical studies and sociological studies of law are in fashion. More publications are available in areas related to law or across disciplines on topics such as mergers and acquisitions, securities, world trade organizations, human rights, health law, social and medical insurance, labor disputes, environmental protection, international relations, and so on. Law libraries' missions have shifted from merely collecting and owning materials to providing services and access inside and outside library walls.

As for legal research, it is still difficult to find statistical data, local laws and government policies, as well as cases. Although more and more English translations of laws and regulations are available, it is very difficult to find English translations of cases. 


\section{Online Resources on East Asian Law in the United States 26}

There are many good, free and easy-to-find electronic resources on Chinese, Japanese or Korean law to be found on the Internet. For information on the most important electronic resources on East Asian law, please consult with these excellent online research guides at the websites of:

LLRX (http:/ / www.llrx.com/comparative_and_foreign_law.html);

Library of Congress (http:/ /www.loc.gov/law/help/foreign.html);

Marian Gould Gallagher Law Library (http:/ / lib.law.washington.edu/eald/eald.html);

GlobaLex (http:/ /lib.law.washington.edu/eald/eald.html).

Provided below are descriptions of selected comprehensive and subscription-based online resources used in the United States.

\section{Mainland China (PRC)}

China Law Info (北大法律信息网):

URL: www.chinalawinfo.com

This database developed by Peking University Law School provides access to a range of Chinese legal materials, including laws and regulations, cases, legal news, gazettes and academic law journals. This database currently is the most comprehensive, up-to-date, and user-friendly electronic resource on PRC law available on the Internet. The database has both Chinese and English language interfaces. It provides English versions of selected laws, regulations and cases.

iSinoLaw (中华法律网):

\section{URL: http://www.isinolaw.com}

This Hong Kong-based website was founded by a group of Chinese legal professionals and experienced entrepreneurs. It is the world's first certified online bilingual provider of China laws, regulations, pronouncements and other legal information. It provides the full text of laws, regulations, judicial interpretations, standard contract forms, analysis, and court judgments. In

26 The analyses are based on my observations at the end of May 2008. Any developments after that date are not covered here. 
addition, there is a section on the WTO and China. This site includes two major databases: 1) English translation of Chinese laws published by The Publishing House of Law as The Laws of the People's Republic of China Series, and 2) English translation of selected Chinese cases published by Butterworth Asia as China Law Reports Series.27 It has four interfaces: English, Simplified Chinese, Traditional Chinese, and Japanese.

Lawyee (北大法意):

URL: http://www.lawyee.net

This database developed by Peking University Positivist Study of Law Institute provides the full text of laws, regulations, judicial interpretations, WTO rules and documents, legal articles, and legal statistics. It is currently the largest data bank of legal cases on PRC law available on the Internet. The cases are searchable by keyword, case number, court name, and judge's name. This is chiefly a Chinese Language database with a small number of documents translated into English.

China Law Reference Service Online (CLRS Online) (中国法律资料库)：

URL: http:/ / www.clrsonline.com

This database, hosted by $\mathrm{CCH}$ Asia Pte Limited, is an extensive source of business laws issued in the PRC since 1979. It provides full, accurate and detailed translations of many of the PRC's major or significant laws, business regulations, and legal news. It is a Chinese and English bilingual database.

\section{Taiwan (ROC)}

Lawdata (月旦法學知識庫):

URL: http://www.lawdata.com.tw

This database developed by Yuanzhao Legal Press provides research materials for the study of ROC law and PRC law. The site includes full-text articles in legal journals, monograph bibliographies, commonly used laws and regulations, an online English-Chinese/Chinese-English law dictionary, judicial decisions from the Supreme Court, citations to Master's and Ph.D.

Wei Luo, Internet Chinese Legal Research Center, available at http://aw.wustl.edu/chinalaw/intersou.html (last visited on Oct. 6, 2008). 
dissertations from Taiwan, and citations to legal articles from the Mainland. The contents of this site are in Chinese.

\section{Japan}

LexisNexis JP:

URL: http://legal.lexisnexis.jp

This database developed by LexisNexis Japan Co. is one of the largest online resources concerning Japanese law. It provides the full text of laws and regulations, cases and commentaries, as well as articles and legal forms. The contents of this site are in Japanese.

D1-Law:

URL: https://www.d1-law.com

This database, developed by Dai-Ichi Hoki Co., Ltd., is also one of the largest online resources on Japanese law. The contents of the database include the full text of laws and regulations, cases, and articles, as well as special sections on intellectual property, tax and accounting laws. This is a Japanese language database.

\section{$\underline{\text { Korea }}$}

LawnB (Law and Business):

URL: http:/ /www.lawnb.com

This is the largest comprehensive online resource on Korean law. This is a Korean language database.

Statutes of the Republic of Korea:

URL: http:/ / elaw.klri.re.kr/indexE.jsp

This is the most comprehensive database of Korean statutes in English. 
YIJUN Institute of International Law(李儶國際法研究院):

URL: http:/ / www.yijuninstitute.org

The YIJUN institute's website is going to offer online digital archives of international law covering treaties, cases, and academic articles under the name $<$ Global Agenda $>$.

\section{Conclusion}

The development of East Asian law collections in the United States has spanned over 100 years. In the early time, libraries relied on gifts, personal connections and acquisition trips to collect East Asian legal materials. Foundations and prominent scholars and individuals also played important roles in the development of East Asian law collections. These random collections received a major boost between 1960s and 1980s when East Asian legal study programs emerged in major law schools. Professional law librarians were hired to systematically collect and organize these materials.

As demands for East Asian law teaching, research and practice have increased in recent years, U.S. law schools and law libraries have seen their East Asian law resources grow significantly. This development complements traditionally strong historical collections as well as ever-growing collections of contemporary, law-related materials in East Asian Studies libraries in the United States. Many East Asian libraries have excellent and unique East Asian law collections. Notable examples include the Harvard-Yenching Library and Fung Library at Harvard, the East Asian Library and the Gest Collection at Princeton University, the East Asian Collection at the University of Chicago, the C.V. Starr East Asian Library at Columbia University and the C.V. Starr East Asian Library at the University of California, Berkeley. In fact, in some universities, the East Asian library, rather than the law library, has traditionally taken the leading role in collecting materials on East Asian law.

Trends are changing, however. In an era of declining library budgets, there is an increasing need to rely on inter- and intra-institutional resource sharing to provide for the diverse, interdisciplinary research needs of faculty and students. Today, as more and more law school libraries realize the importance of collecting East Asian legal resources, it is the major law libraries that are the primary repositories for East Asian legal collections in the United States. 